\title{
Research on the Effect of Internal Control Effectiveness on Enterprise Value-Based on Empirical Data from the Real Estate Iindustry
}

\author{
Yaning Zheng \\ School of Management, University of Science and Technology, Xi'an 710000, China \\ 546381197@qq.com
}

ABSTRACT. In recent years, internal control plays an increasingly important role in the development of the enterprise. In addition, the value management is a kind of new enterprise management mode of creating value for the target, highlighting the core status of enterprise value management idea and promoting the enterprise value has been increased. The paper is based on the Shanghai and Shenzhen main board listed companies, and it analyzes the present situation and problems of internal control about them. Then, this paper regards the internal control the effectiveness of the comprehensive index as explanatory variables and regards enterprise value as the explained variable and regards company size and ownership concentration as control variables. At first, the paper finds the comprehensive score of the internal control's effectiveness by factor analysis. Second, it uses regression analysis of enterprise value by coupling with other variables.In the end,the impact of the effectiveness of internal control on enterprise value is positive.

KEYWORDS: Internal Control, Enterprise Value

\section{Introduction}

In recent years, due to internal control failure property fraud case emerge in endlessly, such as the United States enron knight trading group and China sanlu incident roebuck problem of the island's failure control YiAn science and technology, etc., is a wake-up call to many businesses and one of the real estate industry as a pillar industry in our country, more perfect good internal control system to provide support.

In china,Shanghai and shenzhen main board listed companies since January 1, 2012 began to implement internal control standard system, the internal control of defects and disclosure problems become the focus of theoretical and practical circles in recent years, China's real estate industry to grow rapidly, has been rapid progress 
Academic Journal of Computing \& Information Science

ISSN 2616-5775 Vol. 3, Issue 1: 83-95, DOI: 10.25236/AJCIS.030109

economic crisis recovery process, as the government regulation and control policy and constantly improve, as well as the rapid development of real estate industry, real estate as the indispensable element in people's life, its internal control system and enterprise value by more people's attention In the environment of rapid economic development all over the world, internal control can better reflect the enterprise's operation ability and operation status, and its effective operation can improve the enterprise's management level, and thus improve the core competitiveness of modern enterprises, which has a great positive effect on the improvement of enterprise value.

\section{Definition and measurement of concepts}

\subsection{Internal Control}

\subsubsection{The Meaning of Internal Control}

Internal control is an organization, plan, method, and procedure that is implemented in the company in order to obtain timely, effective, and reliable financial and accounting information and various useful resources in order to achieve high operating efficiency and established management goals. . Whether a given goal can be achieved and to what extent can be measured by the effectiveness of internal control, and its operability requires some financial indicators that can be calculated specifically.

\subsubsection{The Objective of Internal Control}

According to China's "Basic Standards for Enterprise Internal Control", the internal control objectives of an enterprise include the following five: to ensure the legal compliance of business operations and management; to protect the safety of assets; to ensure the true and complete financial reports and related information; to improve the efficiency and effectiveness of operations; to promote the realization of enterprises development strategy.The goal of internal control is the starting point for enterprises to understand the basic theory of internal control, and it is also the key to determine the specific direction of the enterprise's internal control operations and to implement it effectively. If an enterprise wants to maximize the function of internal control, it must Understand and master its goals correctly.

\subsection{Enterprise Value}

\subsubsection{The Meaning of Enterprise Value}

Enterprise value is determined by the profitability of the enterprise. In essence, enterprise value is the sum of the value of profitability and the value of potential profit opportunities on the basis of the existing enterprise, that is, the enterprise value is the existing operations of the enterprise. The sum of the discounted value of the future amount of cash generated by the business plus the value of the profit opportunities that the company has, is composed of the three factors of the company's existing profit, future value increment and sustainable time. 


\subsubsection{The Value Measurement of Enterprise Value}

The main measurement methods of enterprise value including: discounted cash flow model, relative valuation model, market value model, liquidation value model, option pricing model, and EVA model. This article first considers whether the data is available and whether the evaluation is relatively objective. Then it refers to the previous empirical research related to corporate value by many researchers, and finally uses the Tobin Q value to measure corporate value.

3. The Status Quo of Internal Control of Chinese Real Estate Listed Companies and Its Impact on Enterprise Value

\subsection{Status of Internal Control of Listed Companies in Real Estate in China}

3.1.1 The Status Quo of Internal Control in China's Real Estate Enterprises: Starting from the Objectives of Internal Control

Table 1 Main Measurement Indicators of the Status of Real Estate Internal Control

\begin{tabular}{|c|c|c|c|}
\hline & & $\begin{array}{l}\text { Year } \\
2014\end{array}$ & $\begin{array}{l}\text { Year } \\
2015\end{array}$ \\
\hline \multirow[t]{6}{*}{ Profitability } & Earnings per share (average) (yuan) & 0.16 & 0.13 \\
\hline & Net sales margin (average) (\%) & 1972.94 & 2276.42 \\
\hline & Gross profit margin (average) (\%) & 39.26 & -85.75 \\
\hline & Operating cost ratio (average) (\%) & 61.66 & 188.56 \\
\hline & Operating margin (average) (\%) & 2308.43 & -1735.11 \\
\hline & Cost expense margin (average) (\%) & 28.46 & 9.24 \\
\hline \multirow{6}{*}{$\begin{array}{l}\text { Operating } \\
\text { capacity }\end{array}$} & Operating cycle (average) (days) & 897.08 & 3079.00 \\
\hline & Inventory turnover rate (average) (times) & 0.38 & 0.49 \\
\hline & $\begin{array}{l}\text { Accounts receivable turnover rate (average) } \\
\text { (times) }\end{array}$ & 198.16 & 190.89 \\
\hline & $\begin{array}{c}\text { Turnover rate of current assets (average) } \\
\text { (times) }\end{array}$ & 0.13 & 0.13 \\
\hline & Turnover rate of total assets (average) (times) & 0.24 & 0.09 \\
\hline & Turnover rate of fixed assets (average) (times) & 23.67 & 24.67 \\
\hline Asset & Return on total assets (average) (\%) & 0.81 & 0.39 \\
\hline profitability & Return on net assets (average) (diluted) (\%) & 3.21 & 0.82 \\
\hline \multirow{3}{*}{$\begin{array}{l}\text { Cash flow } \\
\text { analysis }\end{array}$} & Sales cash ratio (average) (\%) & -3419.70 & -10705.65 \\
\hline & Net profit cash content (average) & -267.30 & 242.79 \\
\hline & Cash content of operating income (average) & 516.75 & 2026.03 \\
\hline \multirow[t]{2}{*}{$\begin{array}{l}\text { Cash flow } \\
\text { analysis }\end{array}$} & $\begin{array}{l}\text { Year-on-year operating income growth } \\
\text { (average) (\%) }\end{array}$ & 71.50 & 717.47 \\
\hline & Net profit growth (average) (\%) & 204.40 & 2.21 \\
\hline
\end{tabular}

Published by Francis Academic Press, UK 
Academic Journal of Computing \& Information Science

ISSN 2616-5775 Vol. 3, Issue 1: 83-95, DOI: 10.25236/AJCIS.030109

From the perspective of operating efficiency and effectiveness, from Table 2.2, in 2015, the average operating profit rate of all real estate companies changed from 2308.43 in 2014 to -1735.11 , and corporate profitability was insufficient; real estate companies in 2014 By 2015, most of the average operating capacity indicators have remained stable, indicating that the real estate companies have good operating capabilities.

Internal supervision is the basic guarantee for the smooth development of daily operations of real estate enterprises. From the perspective of actual work, the problem of incomplete internal supervision mechanisms exists in most real estate enterprises in China. From the perspective of asset security, the sales cash ratio has changed greatly, and most companies' cash flows have become poor. The probability of companies suffering from financial crisis is slightly greater. Due to the low security of company funds, the current internal control system of some real estate companies in China is always only Under the surface, there are hidden problems in asset security. The business processes of some real estate companies are too fragmented, the funds show regional operation, and the budget management system is not perfect.

From the analysis of the company's strategic goals, the average year-on-year growth rate of the company's net profit was $2.21 \%$, with almost no change. The company's strategic goals were unclear. China's real estate industry lacked effective management mechanisms in terms of information and communication, which led to various departments of the real estate company. They cannot communicate and coordinate in a timely and effective manner, and various aspects of the company's policies cannot be effectively implemented and implemented, and in the end it will affect the promotion of corporate value.

\subsubsection{The Necessity of Internal Control in Real Estate Companies}

(1) Changes in the current environment require real estate companies to strengthen internal controls

In the development stage, China's real estate companies will be affected by national land policies, macro-controls and other policies. In addition, they will also be affected by changes in the investment environment and national politics. Its own long-term development will not help achieve the enhancement of corporate value. Therefore, real estate companies should strengthen their internal controls to help them resist and avoid various unknown risks.

(2) Perfecting and optimizing the internal control system is a requirement for building modern enterprises

In recent years, with the rapid economic growth of our country, the rapid expansion of the real estate industry and the continuous expansion of its scale, various companies have changed in different aspects, which has increased the difficulty of internal control management of the foundation industry to a certain extent. The development of real estate companies is closely related to the effectiveness of their own management and the integrity of the internal control system. Therefore, only by continuously optimizing the internal control system can 
Academic Journal of Computing \& Information Science

ISSN 2616-5775 Vol. 3, Issue 1: 83-95, DOI: 10.25236/AJCIS.030109

we ensure the integrity of the enterprise management system and further achieve the goal of maximizing corporate value.

\subsection{Impact of Internal Control Effectiveness on Enterprise Value}

\subsubsection{From the Perspective of the Five Goals of Internal Control}

(1) Ensuring legal and compliance objectives of business management is a condition for the enhancement of corporate value.

Today's society is both an economic society and a legal society. Legal operation is the prerequisite for organizing all activities of an enterprise. If a company violates the law, it will not only damage its reputation, but also cause it to lose its prestige and reduce its value. Therefore, enterprises should restrain themselves according to the law and ensure that all their production and operation activities are allowed by the law. Only if they have legitimacy can they enhance their own enterprise value, and only then can the company continue to develop.

(2) Protecting asset security is an important guarantee for increasing corporate value.

The security of corporate assets is an important guarantee for normal production and operation activities and obtaining benefits. If the security of assets is threatened, it will affect the company's ability to repay debts and profitability, which is not conducive to enhancing the value of the enterprise.

(3) The true and complete financial report and related information are the basis for enhancing the value of the enterprise.

The reliability and completeness of an enterprise's financial reports and related information will affect external investors' predictions and judgments of the future development of its invested enterprises, which will increase the company's financing ability and be beneficial to the development of the enterprise; in addition, reliable and complete financial information It is conducive to the establishment of an honest corporate culture within the enterprise, and helps all employees to unite as one and work together to achieve corporate value.

(4) Improving business efficiency and effectiveness is the source of increasing corporate value.

The daily business activities are the core of an enterprise and the source of corporate profits and value. Good business activities are conducive for enterprises to fully match and match resources, maximize the use of resources, ensure business efficiency and effectiveness, and thereby increase corporate value.

(5) Promoting enterprises to realize development strategies is the fundamental driving force to enhance enterprise value.

The development strategy goals of the internal control objectives require companies to formulate their own development strategies. From a long-term perspective, they need to guide the development direction of the enterprise, promote 
the sustainable development of the enterprise, and realize the added value of enterprise value.

\subsubsection{From the Overall Perspective of Internal Control}

(1) As internal control theories and systems gradually become popular, citizens gradually understand their far-reaching impact on enterprise value. Therefore, internal control theory has actually promoted the development of enterprise value theory;

(2) The scope of control of internal control includes the daily operations of the enterprise. The subject of corporate value activities is the object of internal control. In addition, the object of corporate value is the content of internal control;

(3) The most important purpose of an enterprise's value activities is to increase the value of the assets of the enterprise on the original basis, which is consistent with the ultimate purpose of implementing internal control, that is, to achieve the enhancement of enterprise value.

\section{Empirical Analysis of the Effect of Internal Control Effectiveness on Enterprise Value}

After the concept definition of the first two chapters and the analysis of the current situation of real estate companies, there is a certain correlation between internal control and corporate value. This chapter will measure the level of internal control of real estate companies from the five goals of internal control, and further study the two through empirical methods.

\subsection{Selection and Source of Sample Data}

This article studies the relationship between the effectiveness of internal control and corporate value. The research object is the 2015 financial data of listed companies in the real estate industry on the Shanghai and Shenzhen A-share main board market. After the sample, a total of 67 companies were selected as the sample for this study. The data used in this article comes from the RESSRT financial research database and NetEase Finance and Economics. The data processing software used is EXCEL and SPSS.

\subsection{Research Hypothesis}

Whether the effectiveness of internal control has an impact on the value of the enterprise. The more effective the internal control is, the more beneficial it is to increase the value of the enterprise; otherwise, it is not conducive to the improvement of the value of the enterprise. After analysis, the research hypothesis made in this paper is that there is a positive relationship between the effectiveness of internal control and corporate value. 
Academic Journal of Computing \& Information Science

ISSN 2616-5775 Vol. 3, Issue 1: 83-95, DOI: 10.25236/AJCIS.030109

\subsection{Selection of Variables}

\subsubsection{From the Overall Perspective of Internal Control}

This article uses Tobin's Q value to represent the value of the enterprise as the explanatory variable for this study.Tobin's $\mathrm{Q}$ value = company market price / company replacement cost $=$ (year-end circulating market value + amount of nonnegotiable shares in net assets + total long-term liabilities + total short-term liabilities) / total assets at the end of the year.

\subsubsection{Explanatory Variables}

The explanatory variable in this article is the effectiveness of internal controls, expressed in ICI. In addition, this article selects the total asset turnover rate, cost rate, operating profit margin, return on net assets, audit opinions (virtual variables, audit opinions of corporate financial reports are standard unqualified opinions, the value is set to 1 , otherwise 0 ) Whether it has been punished for violations (virtual variables, if the company has been punished by a regulatory agency or as a defendant in 2015, the value is 1 , otherwise 0 ), net assets per share, operating profit growth rate, and earnings per share related internal controls Effectiveness evaluation index is used as a substitute variable through factor analysis.

\subsubsection{Control Variable}

(1) Company size, expressed in SIZE. Reading the literature and journal comparisons of previous scholars found that most of them used the total assets of the company at the end of the year when measuring the size of the company. Therefore, in order to ensure the accuracy of the research conclusions, this method is also selected to measure the size of the company.

(2) Degree of equity concentration. This article uses the sum of the shareholding ratios of the top five shareholders of the company to describe the distribution of corporate equity, and uses SHRCR to indicate the degree of equity concentration.

\subsection{Empirical Research Process and Analysis of Results}

\subsubsection{Model Design}

The regression model for empirical research constructed in this article is:

$$
\mathrm{Q}=\beta_{0}+\beta_{1} \mathrm{ICI}+\beta_{2} \mathrm{SIZE}+\beta_{3} \text { SHRCR }+\alpha
$$

Among them, $\alpha$ indicates other factors affecting the value of the enterprise; $\beta 0$ is a constant term, $\beta 1-3$ is the coefficient of each variable. When the coefficient is greater than 0 and significant, it indicates that the variable has a significant positive relationship with the value of the enterprise, otherwise it is a negative relationship.

\subsubsection{Factor Analysis of Effectiveness of Internal Control}

This article uses SPSS software to perform factor analysis. The specific process is to process some previously calculated financial indicators. The KMO and Bartlett tests are used to determine whether it is applicable. Then, the principal factor analysis method is used to extract the common factors, perform factor naming and rotation. Finally, a comprehensive score is calculated according to the weighted 
Academic Journal of Computing \& Information Science

ISSN 2616-5775 Vol. 3, Issue 1: 83-95, DOI: 10.25236/AJCIS.030109

weight of each factor and the factor coefficient analysis table. However, if there are less than two observations in the calculation and analysis, then at least one variable has zero variation. If there is only one variable in the analysis or the correlation coefficient cannot be calculated for all the variables, then no further calculation Statistical data, and according to the RESSRT database statistics show that in 2015 there were no major penalties or defendants for the listed companies in the real estate industry. Therefore, the variables that have been penalized for violations cannot be calculated with their correlation coefficients and cannot be further calculated.

The specific results are as follows: set the original variable cost expense margin (\%), operating profit margin (\%), return on net assets (weighted) (\%), net assets per share (yuan / share), earnings per share (yuan / share ), Audit opinion, operating profit growth rate (\%), total asset turnover rate (times) are $\mathrm{X}_{1}, \mathrm{X}_{2} \ldots \mathrm{X}_{8}$. That is:

$$
\begin{gathered}
\mathrm{F} 1=0.043 \mathrm{X}_{1}-0.031 \mathrm{X}_{2}+0.244 \mathrm{X}_{3}+0.403 \mathrm{X}_{4}+0.375 \mathrm{X}_{5}-0.034 \mathrm{X}_{6}+0.225 \mathrm{X}_{7}- \\
0.289 \mathrm{X}_{8} \\
\mathrm{~F} 2=0.340 \mathrm{X}_{1}+0.424 \mathrm{X}_{2}+0.058 \mathrm{X}_{3}-0.316 \mathrm{X}_{4}-0.145 \mathrm{X}_{5}+0.015 \mathrm{X}_{6}-0.013 \mathrm{X}_{7}+ \\
0.567 \mathrm{X}_{8} \\
\mathrm{~F} 3=-0.125 \mathrm{X}_{1}-0.130 \mathrm{X}_{2}-0.034 \mathrm{X}_{3}+\mathrm{O}-263 \mathrm{X}_{4}+0.036 \mathrm{X}_{5}+0.834 \mathrm{X}_{6}-0.286 \mathrm{X}_{7}+ \\
0.207 \mathrm{X}_{8}
\end{gathered}
$$

Finally, the comprehensive score (ICI) of the effectiveness of internal control of each sample company is calculated. The variance contribution rate of the three factors is used as the weight, and the method of factor-weighted total score is used, that is:

$$
\mathrm{ICI}=\mathrm{F}_{0} / 74.388=\left(21.053 \mathrm{~F}_{1}+35.673 \mathrm{~F}_{2}+43.275 \mathrm{~F}_{3}\right) / 74.388
$$

\subsubsection{Descriptive Statistical Analysis}

Descriptive statistical analysis of the data involved in this study through SPSS software, the results are as follows:

Table 2 Variable Descriptive Statistics

\begin{tabular}{cccccc}
\hline & $\mathrm{N}$ & Minimum & Maximum & Mean & Standard Deviation \\
\hline Enterprise value (Q) & 67 & 0.148 & 21.554 & 1.616 & 3.350 \\
ICI & 67 & -60.968 & 265.288 & 13.563 & 44.167 \\
SHRCR & 67 & 0.175 & 0.871 & 0.529 & 0.153 \\
SIZE(billion) & 67 & 3.7 & 6004.4 & 428.867 & 897.549 \\
\hline
\end{tabular}

(1) Based on factor analysis, the sample company's comprehensive score is 265.288 , the lowest is -60.968 , and the average is 13.563 , indicating that the effectiveness of the internal control of the real estate industry in China is good. There are certain differences in operation, sale, and internal control systems, so it can be concluded that there is a gap between the effectiveness levels of internal control of different enterprises. 
(2) The average equity concentration is $52.93 \%$, the highest is $87.07 \%$, and the lowest is only $17.54 \%$. It can be concluded from this: there are also significant differences in the ownership structure and concentration among many companies in the real estate industry.

(3) The highest scale of the company is 6004.4, the lowest is 3.7, and the average is 428.867, which indicates that the assets scale of China's real estate industry is relatively large and the differences between enterprises are also large.

\subsubsection{Regression Analysis}

(1) Goodness of fit test

Table 3 Model Summary

\begin{tabular}{ccccc}
\hline Model & $\mathrm{R}$ & $\mathrm{R}^{2}$ & Adjusted $\mathrm{R}^{2}$ & Standard skew error \\
\hline 1 & $0.558 \mathrm{a}$ & 0.311 & 0.112 & 1.370 \\
\hline
\end{tabular}

a. Forecast: (constant), ICI

According to the numerical analysis in Table 3 above, if $\mathrm{R}^{2}=0.311$ and adjusted $\mathrm{R}^{2}=0.112$, less than 0.5 , the model fits well; in addition, the standard skewness error value is 1.37 , indicating that the model does not have autocorrelation.

(2) Significance Test

Table 4 Significance Analysis

\begin{tabular}{cccccc}
\hline & sum of square & df & Mean square & F & Saliency \\
\hline Return & 2.464 & 1 & 2.464 & 11.217 & $0.004(\mathrm{a})$ \\
Residual & 738.083 & 65 & 11.355 & & \\
Total & 740.547 & 66 & & & \\
\hline
\end{tabular}

a. Contingency Number: Enterprise Value (Q)

b. Forecast value: (constant), SHRCR, ICI, SIZE (billion)

It can be seen from Table 4 that the $F$ value of the model is 11.217 , and the corresponding probability is approximately 0 , below 0.01 . If the model passes the significance test, the linear model is reasonable.

(3) Multiple Regression Results

Table 5 Rregression Analysis

\begin{tabular}{cccccc}
\hline & \multicolumn{2}{c}{ Non-standardized coefficient } & Normalization coefficient & T & Saliency \\
& B & Standard error & Beta & & \\
\hline (constant) & 3.050 & 1.505 & & 2.026 & 0.007 \\
ICI & 0.104 & 0.109 & 0.064 & 2.104 & 0.006 \\
SIZE(billion) & -0.144 & 0.000 & -0.127 & -2.013 & 0.009 \\
SHRCR & $-0 . .98$ & 0.104 & -0.150 & -1.761 & 0.140 \\
\hline
\end{tabular}

a. Contingency number: Enterprise value (Q) 
Academic Journal of Computing \& Information Science

ISSN 2616-5775 Vol. 3, Issue 1: 83-95, DOI: 10.25236/AJCIS.030109

Regression model: $\mathrm{Q}=3.050$ + 0.104ICI-0.144SIZE-0.098SHRCR $+\alpha$

From the analysis in Table 5 above, it can be concluded:

(1) The coefficient of influence of the effectiveness of internal control on the value of the company is 0.104 , and the absolute value of the $T$ value is greater than 2 , the $\mathrm{P}$ value is 0.003 , and less than $5 \%$, so the parameter variable is significant at the $5 \%$ confidence level. $\mathrm{T}$ value test, the internal control has a positive impact on the value of the enterprise, that is, the more effective the internal control of the enterprise, the more beneficial it is to the improvement of the enterprise value, which is consistent with the previous assumptions.

(2) The scale of the company has a negative relationship with the value of the company. The absolute value of the $\mathrm{T}$ value in the table is greater than 2 and the $\mathrm{P}$ value is less than $5 \%$. It can be concluded that the parameter variable is significant at the $5 \%$ confidence level. Pass the $\mathrm{T}$ value test. In general, the scale of the real estate industry is generally relatively large. The larger the scale of the enterprise, the higher the requirements of the various regulations of the company will inevitably be. If the company expands blindly for the speed of development, it will not increase the intensity of control. With the improvement of the management system related to the enterprise, it is easy to ignore internal management issues, which is not conducive to the improvement of corporate value.

(3) There is a significant negative correlation between equity concentration and corporate value. Due to the large amount of capital required by the real estate industry and the large scale of capital, individual shareholders have abandoned their overall interests in order to pursue their own interests, reducing the overall value of the enterprise. The $\mathrm{P}$ value is greater than 0.1 , and the correlation between the two is not significant.

\section{Research Conclusions and Countermeasures}

\subsection{Research Conclusions}

Through empirical research on the empirical data of listed companies in China's real estate industry, this paper analyzes the impact of the effectiveness of internal control on corporate value and draws the following conclusions: The higher the degree of effectiveness of corporate internal control, the more conducive to the enhancement of corporate value . In recent years, China's real estate companies have ignored the issue of internal management due to the emphasis on project development, which has led to an increase in the vacancy rate in today's society. Although China and local governments have issued a series of regulations and measures for the real estate industry, The level of control is still low. China should attach importance to the internal control of the real estate industry, and increase efforts to improve and further optimize the internal control system of enterprises in order to maximize corporate profits and thereby increase corporate value. 
Academic Journal of Computing \& Information Science

ISSN 2616-5775 Vol. 3, Issue 1: 83-95, DOI: 10.25236/AJCIS.030109

\subsection{Suggestions}

According to the previous research conclusions, the following suggestions are made:

(1) Real estate companies strengthen their awareness of internal control

At present, most real estate companies are committed to their own development, while ignoring the establishment of their own internal control system. Weak awareness of internal control affects the overall development of the enterprise and is not conducive to the improvement of corporate value. Therefore, real estate companies should develop moderately according to their actual conditions and not blindly expand. In addition, in the process of operation, enterprises should pay attention to the establishment of perfect internal control systems, and in accordance with their own conditions, establish scientific business processes so that all Businesses can be effectively combined to allow employees to establish the correct concept of internal control, thereby promoting business operations and maximizing corporate profits.

(2) Relevant supervisory departments should strengthen supervision of information disclosure of internal control of real estate companies

Relevant departments shall regularly or irregularly supervise the integrity and authenticity of corporate internal control reports and audit reports of certified public accountants, and formulate relevant norms and measures. Once illegal acts are found, they shall be strengthened to punish them to avoid collusion and fraud. Wait for the unhealthy wind to exist.

\section{(3) Improve the internal control environment}

First of all, enterprises should optimize their internal structure and enhance the communication between various departments. In addition, cultivate corporate culture and establish a reasonable incentive system so that employees can realize their own value when they contribute to the enterprise. A good internal control environment helps the company's employees to unite as one, thereby promoting the development of the company and continuously increasing the value of the company.

\section{Literature References}

Whisenant et.al (2003) [1] pointed out that there is a positive correlation between the level of internal control and stock prices by studying companies with internal control defects, that is, for companies with internal control defects, investors will It is more sensitive, and the company's stock price has dropped significantly, indicating that investors' valuation of corporate value will be affected by the quality of its internal control.

Ashbaugh-Skaife et al. (2008) [2] pointed out that good internal control can reduce the probability and impact of corporate decision errors, and also prevent 
Academic Journal of Computing \& Information Science

ISSN 2616-5775 Vol. 3, Issue 1: 83-95, DOI: 10.25236/AJCIS.030109

companies from conducting earnings management and issuing false financial reports, which indirectly affects corporate value.

Zheng Jun, Lin Zhonggao et al. (2007) [3] analyzed the internal control system's impact on the value of listed companies first in theory. When analyzing relevant data of listed companies, it was concluded that with the continuous improvement of internal control System to improve the quality of the internal control system. As the level of internal control increases, the corporate value of listed companies will also increase.

Yan Huixian (2009) [4] used the three control objectives in the COSO report as the measure of internal control, studied the correlation between internal control and corporate value, and found that companies with higher operating efficiency have greater corporate value, and both The relationship between them is more significant, while the compliance of laws and regulations and the reliability of financial reports have no significant impact on corporate value.

Wang Yang (2013) [5] studied the impact of the effectiveness of internal control on the value of the company based on the five goals of internal control, and pointed out the legal compliance of internal control operations, asset security, operating efficiency and effectiveness, and strategy through empirical analysis. The goals achieved are positively related to the value of the enterprise, and it is concluded that the value of the enterprise will be affected by the effectiveness of internal control.

Ruan Lei (2016) [6] used panel data to study the economic consequences of China's listed companies after implementing internal control, and pointed out that the implementation of internal control will bring about an increase in working capital productivity and turnover rate, and there is also a significant positive relationship with corporate value. Correlation relationship; In addition, by introducing the interaction between financial decision and internal control, it is empirically concluded that effective financial decision of the enterprise can improve the effect of internal control on the value of the enterprise.

Xie Fan, Cao Jian et al. (2016) [7] pointed out that the realization of corporate internal control objectives is negatively related to internal control deficiencies, and the correlation is also affected by the company's listing period and company size. Specifically, the company's asset safety objectives and internal control deficiencies have a negative correlation, but this correlation exists only in companies with short listing years; the efficiency of corporate operations and the achievement of strategic goals are also negative to internal control deficiencies. Relevant, and this relationship only exists in larger companies.

Zhou Meihua and Lin Bin (2016) [8] studied the impact of internal control on corporate internal corruption caused by management rights in the background of anti-corruption in recent years, and pointed out that internal control of enterprises can curb corporate corruption; It can be seen that the control environment and risk assessment of an enterprise have a more significant inhibitory effect on corruption, which indicates that a good control environment and risk assessment in an enterprise 
Academic Journal of Computing \& Information Science

ISSN 2616-5775 Vol. 3, Issue 1: 83-95, DOI: 10.25236/AJCIS.030109

can reduce the agency costs caused by managers chasing their own interests to a certain extent.

Wang Xinhong, Zhang Xing, and Xue Zerong (2018) [9] analyzed the pledge behavior of major shareholders of 4,788 listed companies in A shares through research, and explored the relationship between major shareholder equity pledge, internal control, and company performance. It is found that a high proportion of equity pledge by large shareholders will significantly reduce the company's performance level, and a company's high-quality internal control system can significantly improve the company's performance level. Further research finds that a company's high-quality internal control system can weaken the negative effect of large shareholder equity pledge on company performance, that is, internal control plays a significant negative regulating role.

\section{References}

[1] Whisenant.,J.S.,S. Sankaraguruwamy. And K. Raghunandan. Market reactions to disclosure of reportable events [J]. Auditing: A Journal of Practice and Theory, 2003 (3): 20-30.

[2] Ashbaugh,H.,D. Collins, W. Kinney, R. LaFond. The effect of internal control deficiencies onfirm risk and cost of equity capital, Working paper [D]. University of Wisconsin Madison, 2006 (8): 50-55.

[3] Zheng Jun, Lin Zhonggao. Can high-quality internal control increase commercial credit financing? A test based on the perspective of monetary policy changes [J]. Accounting Research, 2013 (6): 62-68.

[4] Yan Huixian.Empirical Research on the Impact of Internal Control on Enterprise Value [D]: [PhD Dissertation]. Jinan University, 2009.

[5] Wang Yang. An empirical study on the effect of the effectiveness of internal control on corporate value [D]: [Master Degree Thesis]. Lanzhou University, 2013.

[6] Ruan Lei. Research on the Economic Consequences of Internal Control of Chinese Listed Companies [D]: [PhD Dissertation]. Jilin University, 2016.

[7] Xie Fan, Cao Jian, Chen Ying, etc. Analysis of the Economic Consequences of the Disclosure of Internal Control Defects: Based on the Perspective of the Enforcement of Internal Control of Listed Companies [J]. Accounting Research, 2016 (9): 62-67.

[8] Zhou Meihua, Lin Bin, Lin Dongjie. Management Rights, Internal Control and Governance of Corruption [J]. Accounting Research. 2016, (3): 56-63.

[9] Wang Xinhong, Zhang Xing, Xue Zerong. A Study on the Impact of Large Shareholders' Equity Pledge on Corporate Performance-Based on the Moderating Role of Internal Control [J]. Friend of Accounting, 2018 (10): 58-64. 